\title{
Chemical composition and antibacterial activity of the essential oils of Ferula vesceritensis Coss et Dur. leaves, endemic in Algeria
}

\author{
Amar Zellagui ${ }^{1}$, Noueddine Gherraf ${ }^{1 *}$ and Salah Rhouati ${ }^{2}$
}

\begin{abstract}
Background: The biological importance of members of genus Ferula promoted us to investigate the leaves of Ferula vesceritensis Coss et Dur. (endemic plant) previously not investigated. This study presents the chemical composition and antibacterial activities of the hydrodistilled oils.

Results: Volatile components of the leaves of $F$. vesceritensis have been studied by gas chromatography-mass spectrometry to afford 23 compounds. The major components were found to be 5,9-tetradecadiyne (24.72\%), germacrene D (24.51\%), farnesene (8.57\%), and a-bisabolene (8.57\%). The antimicrobial activities of the essential oils were evaluated by disk diffusion method and tested against Gram-positive and Gram-negative bacteria. The volatile oil showed a strong antibacterial activity against Staphylococcus aureus, Escherichia coli, and Klebsiella pneumonia.

Conclusions: These results reinforce the previous studies showing that the genus Ferula is considered as a good source of essential oils. The results presented here can be considered as the first information on the antimicrobial properties of $F$. vesceritensis.
\end{abstract}

Keywords: Ferula vesceritensis, Volatile oils, GC-MS, Antimicrobial activity

\section{Background}

Since the middle ages, essential oils have widely been used for bactericidal, virucidal fungicidal, antiparasitical, insecticidal, medicinal, and cosmetic applications, especially nowadays in pharmaceutical, sanitary, cosmetic, and agricultural and food industries. Because of the mode of extraction, mostly by hydrodistillation from aromatic plants, they contain a variety of volatile molecules such as terpenes and terpenoids, phenol-derived aromatic components, and aliphatic components [1].

The exclusively old-world genus Ferula, belonging to the family Apiaceae, has some 130 species distributed throughout the Mediterranean area and Central Asia. These plants are often used as spices and in the preparation of local drugs. The resins are reported to be used for stomach disorders such as a febrifuge and carminative agent [2]. Some species are used in traditional medicine for the treatment of

\footnotetext{
* Correspondence: ngherraf@yahoo.com

'Laboratory of Biomolecules and Plant Breeding, Life Science and Nature Department, Faculty of Exact Science and Life Science and Nature, University of Larbi Ben Mhidi, Oum El Bouaghi, Algeria

Full list of author information is available at the end of the article
}

skin infections [3] and hysteria [2]. Previous study dealing with members of this genus revealed that the main constituents are sesquiterpenes and sesquiterpene coumarins. More than 70 species have been studied chemically leading to the fact that germacranes, humulanes, carotanes, himachalanes, and guaianes represent the main sesquiterpene constituents of the genus [4-10]. Ferula spp. are also known for their toxicity and pharmacology. Daucane esters from $F$. communis and Ferula arrigonii showed antiproliferative activity on human colon cancer lines [11] and calcium ionophoretic and apoptotic effects in the human jurkat T-cell line [12].

Ferula vesceritensis belongs to umbelifereae family, which widely spread in north Africa, this plant is abundant in south east of Algeria. The genus Ferula represented in Algeria by six species [13].

Ferula vesceritensis is indigenous to Algerian Sahara. According to ethnobotanical investigation, fruit decoction is used in folk medicine to treat headaches, fever, and throat infections, while the livestock avoids grazing it [14]. 
Our continuation of investigation carried out on $F$. vesceritensis [15-17]. The essential oils of the leaves of $F$. vesceritensis led to the identification of 23 compounds. Moreover, the evaluation of the antibacterial activity of the essential oils revealed a very important effect against some bacteria strains.

\section{Methods}

\section{Gas chromatography/mass spectroscopy}

GC/MS analysis was carried out on a ThermoquestFinnigan Trace GC/MS instrument equipped with a DB1 fused silica column $(30 \mathrm{~m}, 0.25 \mathrm{~mm}$ i.d., film thickness $0.25 \mathrm{~m}$ ). The oven temperature was raised from 60 to $250^{\circ} \mathrm{C}$ at a rate of $5^{\circ} \mathrm{C} / \mathrm{min}$ then held at $250^{\circ} \mathrm{C}$ for $10 \mathrm{~min}$; transfer line temperature was adjusted at $250^{\circ} \mathrm{C}$. Helium was used as the carrier gas at a flow rate of $1.1 \mathrm{~mL} / \mathrm{min}$ with a split ratio of $1 / 50$. Identification of the constituents of each oil was achieved by comparison of their mass spectra and retention times (Rt) with those reported in the literature, and those of authentic samples.

\section{Antimicrobial activity}

The antibacterial activity test was carried out on essential oils of the leaves of $F$. vesceritensis roots using disk diffusion method (NCCLS) against four human pathogenic bacteria, including Gram positive, Gram-negative bacteria.

\section{Results and discussion}

This study focused essentially on the phytochemical and antibacterial screening of $F$. vesceritensis. The specie has been screened for seven chemical groups. The analyses reveal the presence of volatile oils, flavonoids, saponins, tannins, carotenoids, and coumarins (Table 1).

Essential oils from the leaves of $F$. vesceritensis have been studied by GC-MS to afford 23 components. The yield was $1.82 \%$ on dry weight basis. In previous studies, the essential oil obtained from the roots of Ferula ferulaoides yielded $2.4-3.2 \%$ of essential oil from dry roots [18] and average $1,66-3.85 \%$ in the fruits of Ferula gummosa [19]. The essential oil components identified from $F$. vesceritensis are

Table 1 Phytochemical screening from $F$. vesceritensis

\begin{tabular}{llllll}
\hline Chemical groups & Roots & Leaves & Stems & Flowers & Fruits \& seeds \\
\hline Volatile oils & ++ & +++ & ++ & +++ & +++ \\
Carotenoids & + & + & + & + & ++ \\
Alkaloids & - & - & - & - & - \\
Flavone aglycones & + & + & +- & + & +- \\
Coumarins & +++ & +++ & +++ & +++ & +++ \\
Tanins & + & + & + & + & + \\
Saponins & ++ & - & - & - & - \\
Flavone glycosides & - & ++ & ++ & ++ & ++ \\
\hline
\end{tabular}

listed in Table 2; the major components were found to be 5,9-tetradecadiyne $24.72 \%$, germacrene D (24.51\%), farnesene (8.57\%), $\alpha$-bisabolene (8.57\%). Some other compounds were only present in minor amounts.

Concerning the chemical composition of the essential oil of other Ferula species, Shatar [18] showed that the roots of F. ferulaoides growing in Mongolia were dominated by Guaiol (58.76\%), and (E)-nerolidol (10.16\%). In the fruits of $F$. gummosa from Iran, the major components were $\beta$-pinene (43.78\%), $\alpha$-pinene $(27.27 \%)$ [20], also found $\beta$-pinene (43.78\%), $\alpha$-pinene $(27.27 \%)$ of $F$. gummosa growing in Isfahan [19], also reported that the essential oil of the Ferula latisecta collected in Iran was characterized by high contents of (Z)-Ocimenone (32.4\%), (E)-ocimenone (20.3\%), and cis-pinocarvone (11.4\%) [21].

\section{Antibacterial activity}

The antimicrobial activities and toxicity of essential oil have been documented, but their modes of action are complex and still in some cases unknown, considering the large number of different groups of chemical compounds present, this activity is due to the presence of active

Table 2 Chemical composition of essential oils from $F$. vesceritensis

\begin{tabular}{|c|c|c|}
\hline Compounds & Rt & $\%$ \\
\hline Ocimene & 07.105 & 0.31 \\
\hline Limonene & 10.554 & 0.12 \\
\hline Fuseloel & 13.587 & 0.11 \\
\hline Nerylacetone & 17.852 & 4.45 \\
\hline Dihydrocarvyl acetate & 20.183 & 6.20 \\
\hline Z-ocimene & 22.290 & 03.19 \\
\hline a-methyl pentenal & 23.193 & 0.42 \\
\hline 5,9-tetradecadiyne & 24.851 & 24.72 \\
\hline 1,1-methylene-3-(propenylidene)-5-vinylcyclohexane & 25.026 & 0.69 \\
\hline Calarene & 25.173 & 2.59 \\
\hline Farnesene & 25.358 & 2.71 \\
\hline a-bisabolol & 26.632 & 0.89 \\
\hline Dihydrocarveol acetate & 26.769 & 1.59 \\
\hline A-Bisabolene & 26.925 & 0.53 \\
\hline Nerolidol Rep & 27.203 & 1.02 \\
\hline Xanth ou a farnesene & 27.402 & 2.00 \\
\hline citral & 27.595 & 0.89 \\
\hline Cububene & 27.902 & 8.57 \\
\hline Germacrene D & 28.311 & 24.51 \\
\hline Nerolidol & 31.634 & 1.55 \\
\hline Bisabolol & 32.213 & 8.57 \\
\hline linalol & 34.691 & 4.35 \\
\hline Total & & 99.98 \\
\hline
\end{tabular}

Bold entries highlight the major components. 
Table 3 Inhibition effect of essential oils from $\boldsymbol{F}$. vesceritensis

\begin{tabular}{lllllcc}
\hline Bacteria & $\mathbf{2 5 0} \boldsymbol{\mu g} / \mathbf{m L}$ & $\mathbf{5 0 0} \boldsymbol{\mu g} / \mathbf{m L}$ & $\mathbf{1 0 0 0} \boldsymbol{\mu g} / \mathbf{m L}$ & $\mathbf{2 0 0 0} \boldsymbol{\mu g} / \mathbf{m L}$ & $\mathbf{4 0 0 0} \boldsymbol{\mu g} / \mathbf{m L}$ & $\mathbf{8 0 0 0} \boldsymbol{\mu g} / \mathbf{m L}$ \\
\hline Escherichia coli ATCC $\mathbf{2 5 9 2 2}$ & $14.5 \pm 0.75$ & $19.0 \pm 0.95$ & $19.0 \pm 0.81$ & $21.5 \pm 0.57$ & $22.0 \pm 0.57$ & $26 \pm 1.25$ \\
Klebsiella pneumonia & $11.5 \pm 0.0$ & $13.5 \pm 0.5$ & $15.0 \pm 0.95$ & $20.5 \pm 0.95$ & $22.5 \pm 0.95$ & $24.5 \pm 0.57$ \\
S. aureous & $12.5 \pm 0.57$ & $14 \pm 0.57$ & $14.5 \pm 0.5$ & $17 \pm 1.21$ & $19.5 \pm 1.29$ & $27 \pm 0.81$ \\
Pseudomonas aerugenosa ATCC $\mathbf{2 7 8 5 3}$ & & 06.00 & $7 \pm 1.73$ & $11 \pm 0.81$ & $13.5 \pm 1.15$ & $16 \pm 1.41$ \\
\hline
\end{tabular}

constituents, mainly attributable to isoprenes such as monoterpenes, sesquiterpenes, and related alcohols, other hydrocarbons and phenols [1].

The diffusion test was applied to four microorganisms including Gram-positive, -negative bacteria. The results summarized in Table 3 showed that the volatile oil from F. vesceritensis prevented the growth of all the tested microorganisms and it has been revealed that the medium diameter of inhibition zone increase proportionally with the increase of concentrations.

The obtained inhibition zone varied from 6.00 to $27.00 \mathrm{~mm}$ with a highest inhibition zone recorded with Staphylococcus aureus at $8 \mathrm{mg} \mathrm{mL}$ and with $26 \mathrm{~mm}$ at $E$. coli in the same concentration. This results corresponding with those obtained on F. gummosa and F. latisecta [20]. It should be mentioned that there are no background antibacterial studies on $F$. vesceritensis.

\section{Experimental}

\section{Plant material}

The leaves of $F$. vesceritensis were collected on May 2010 near Ghardaya Algeria. The plants were identified by Dr. M. Chahma, Faculty of Sciences, University of Ourgla, Algeria, voucher specimens were deposited at the Chemistry Department, University of MentouriConstantine under code number (AM\#112).

\section{Extraction}

Essential oils were obtained by hydrodistillation of $150 \mathrm{~g}$ of dried aerial parts using a Clevenger-type apparatus for $3 \mathrm{~h}$. Diethyl ether $(10 \mathrm{~mL})$ was used as the collector solvent as reported in literature. After evaporation of the solvent, the oil was dried over anhydrous sodium sulfate and stored in sealed vials protected from the light at $-20^{\circ} \mathrm{C}$ before analyses. Three oil samples were obtained by hydrodistillation and subsequently analyzed by GC-MS.

\section{Antimicrobial activity Microorganism strains}

All of the bacteria; standard strains E. coli ATCC 25922, P. aerugenosa ATCC 27853 and (clinical stains: S. aureus, K. pneumonia) were obtained from Bacteriology Laboratory Constantine Hospital University (C.H.U).

The bacterial strains were first grown on Muller Hinton medium (MHI) at $37^{\circ} \mathrm{C}$ for $24 \mathrm{~h}$ prior to seeding on to the nutrient agar. A sterile 6-mm-diameter filter disk
(Whatman paper no. 3) was placed on the infusion agar seeded with bacteria, and each extract suspended in water was dropped on to each paper disk $(40 \mu \mathrm{L}$ per disk) for all of prepared concentrations $(8,4,2,1,0.5$, $0.25 \mathrm{mg} / \mathrm{mL}$ ). The treated Petri dishes were kept at $4^{\circ} \mathrm{C}$ for $1 \mathrm{~h}$, and incubated at $37^{\circ} \mathrm{C}$ for $24 \mathrm{~h}$. The antibacterial activity was assessed by measuring the zone of growth inhibition surrounding the disks. Each experiment was carried out in triplicate.

\section{Conclusions}

Our study of the Algerian F. vesceritensis leaves led to the extraction and characterization of 23 compounds followed by the evaluation of antimicrobial activity for the first time. These results reinforce the previous studies showing that the genus Ferula is considered as a good source of essential oils. The results presented here can be considered as the first information on the antimicrobial properties of $F$. vesceritensis.

\section{Competing interests}

The authors declare that they have no competing interests.

\section{Author details}

${ }^{1}$ Laboratory of Biomolecules and Plant Breeding, Life Science and Nature Department, Faculty of Exact Science and Life Science and Nature, University of Larbi Ben Mhidi, Oum El Bouaghi, Algeria. ${ }^{2}$ Laboratory of Natural Products and Organic Synthesis, Department of Chemistry, Faculty of Science,

University of Mentouri-Constantine, Constantine, Algeria.

Received: 24 December 2011 Accepted: 17 April 2012

Published: 3 September 2012

\section{References}

1. Bakkali F, Averbeck D, Idaomar MM (2008) Biological effects of essential oils-a review. Food Chem Toxicol 46:446-475

2. Boulus L (1983) Medicinal plants of North Africa. Algonae, MI, p 183

3. Appendino G, Spagliardi P, Cravotto G, Pocock V, Milligan S (2002) Daucane phytoestrogens: a structure-activity study. J Nat Prod 65:1612-1615

4. Gonzalez AG, Barrera JB (1995) Chemistry and the sources of mono and bicyclic sesquiterpenes from Ferula species. Progress Chem Org Nat Prod $64: 1-92$

5. Appendino G, Jakupovic J, Alloatti S, Ballero M (1997) Daucane esters from Ferula arrigonii. Phytochemistry 45:1639-1643

6. Kojima K, Isakam K, Ondognii P, Zevgeegiino O, Gombosurengyin P, Davgiin K, Mizukami H, Ogihiara Y (2000) Sesquiterpenoid derivatives from Ferula feruloides IV. Chem Pharm Bull 48:353-356

7. Murray RDH (1989) Coumarins. Nat Prod Rep 6:591-624

8. Ahmed AA (1999) Sesquiterpenes coumarins and sesquiterpenes from ferula senaica. Phytochemistry 50:109-112

9. Nagatsu A, Isaka K, Kojima K, Ondognii P, Zevgeegiin O, Gombosurengyin P, Davgiin K, Irfan B, lqubal CM, Ogihara Y (2002) New sesquiterpenes from Ferula ferulaeoides. Chem Pharm Bull 50:675-677

10. El-Razek MH, Ohta S, Hirata T (2003) Terpenoid coumarins of the genus Ferula. Heterocycles 60:689-716 
11. Poli F, Appendino G, Sachetti G, Ballero M, Maggiano N, Ranaletti FO (2005) Antiproliferative effects of daucanes esters from Ferula communis and Ferula arrigonii on human colon cancer cell lines. Phytother Res 19:152-157

12. Macho A, Blanco-Molina M, Spagliardi P, Appendino G, Bremner P, Heinrich M, Fiebich BL, Munoz E (2004) Calcium ionophoretic and apoptotic effects of ferutinin in the human jurkat line. Biochem Pharmacol 68:875-883

13. Quezel P, Santa S (1962) Nouvelle flore d'Algérie et des régions désertiques méridianales. CNRS, Paris, p 672

14. Oughlissi-Dehak K, Lawton P, Michalet CB, Darbour SN, Hadj-Mahammed M, Badjah-Hadj A, Dijoux Franca MG, Guilet D (2008) Sesquiterpenes from aerial parts of Ferula vesceritensis. Phytochemistry 69:1933-1938

15. Ahmed AA, Mohamed-Elamir FH, Zellagui A, Rhouati S, Tarik A, Ahmed AM, Sayed MA, Shinji Ohta TH (2007) Ferulsinaic acid, a sesquiterpene coumarin with a rare carbon skeleton from Ferula species. Phytochemistry 68:680-686

16. Lahouel M, Zini R, Zellagui A, Rhouati S, Carrupt PA, Morin D (2007) Ferulenol specifically inhibits succinate ubiquinone reductase at the level of the ubiquinone cycle. Biochem Biophys Res Commun 355:252-257

17. Boussenane HN, Kebsa W, Boutabet K, Rouibah H, Benguedouar L, Rhouati S, Alyane M, Zellagui A, Lahouel M (2009) Disruption of mitochondrial membrane potential by ferulenol and restoration by propolis extract. Antiapoptotic role of propolis. Acta Biologica Hungarica 60(4):385-398

18. Shatar S (2005) Essential oil of Ferula ferulaoides from Western Mongolia. Chem Nat Compd 41:5

19. Talebi KE, Naghavi MR, Alayhs M (2008) Study of the essential oil variation of Ferula gummosa samples from Iran. Chem Nat Compd 44:1

20. Ghasemi Y, Faridi P, Mehregan I, Mohagheghzadeh A (2005) Ferula gummosa fruits: an aromatic antimicrobial agent. Chem Nat Compd 41:3

21. Zohreh H, Peyman S, Yousefi M, Hejazi Y, Laleh A, Mozaffarian V, Masoudi S, Rustaiyan A (2006) Chemical composition and antimicrobial activity of the essential oils of Ferula latisecta and Mozaffariania insignis from Iran. Chem Nat Compd 42:6

doi:10.1186/2191-2858-2-31

Cite this article as: Zellagui et al:: Chemical composition and antibacterial activity of the essential oils of Ferula vesceritensis Coss et Dur. leaves, endemic in Algeria. Organic and Medicinal Chemistry Letters 2012 2:31.

\section{Submit your manuscript to a SpringerOpen ${ }^{\circ}$ journal and benefit from:}

- Convenient online submission

- Rigorous peer review

- Immediate publication on acceptance

- Open access: articles freely available online

- High visibility within the field

- Retaining the copyright to your article

Submit your next manuscript at $\gg$ springeropen.com 